\title{
Session 2: Teacher Mobility, Gender and Status, II
}

Ms Samidha Garg, who chaired the second session, invited Dr Paul Miller and Dr Roli Degazon-Johnson to continue discussion of the theme of teacher mobility, gender and status. Dr Miller presented a paper entitled 'Migrant, Male and Married', a personal case study of his experiences as a teacher recruited to work in the European Union.

He began by addressing some of the factors behind teacher migration:

- Direct recruitment — or head-hunting conducted by recruitment agencies and head teachers;

- Voluntary migration, when the teacher decided to travel to another country at their own cost and seek employment on their own initiative;

- Forced migration, when although they might prefer to remain in their country of origin, civil unrest, famine, disease or threat of torture impelled a teacher to leave;

- Migration for reasons of family reunification, when a spouse and children joined an already relocated partner (Hutchings, 2002).

He argued that organised and comprehensive orientation and induction of newly recruited teachers was essential and pivotal to their early and continued success in their new country. Such orientation should focus on:

- Teachers' rights and responsibilities;

- Support mechanisms available from local authorities, trade unions and community organisations;

- System-specific approaches to teaching methodology and pedagogy;

- Classroom management of pupil behaviour;

- Opportunities for training and professional development.

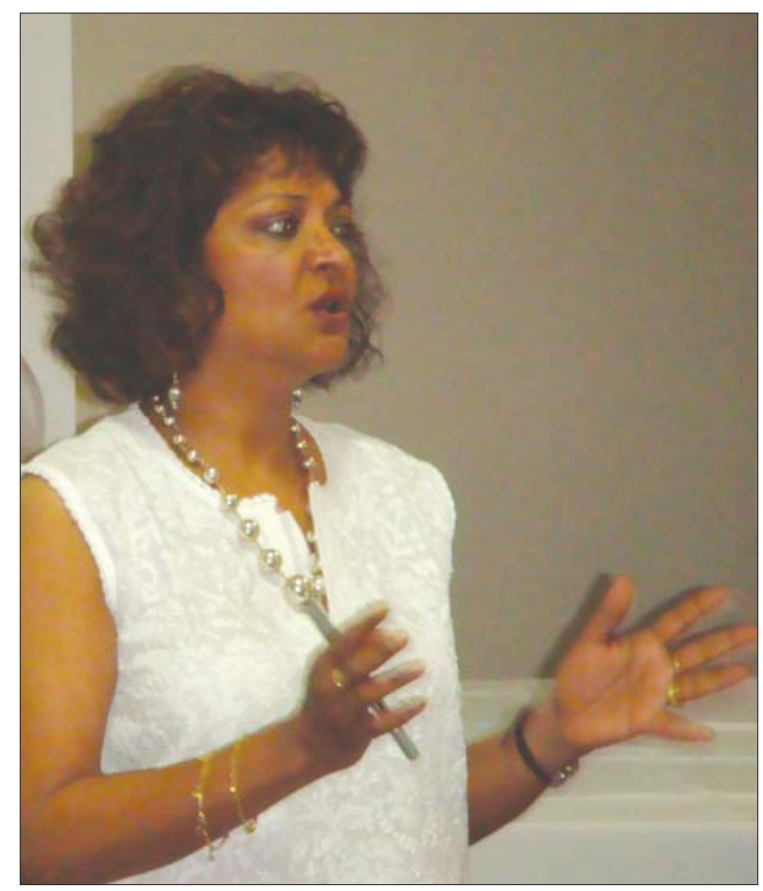

Ms Samidha Garg

He said that his five-day orientation exercise did not focus on any of these, but showed him how to use the interactive whiteboard, which was very useful, provided some pupil data, which was not of use until much later, and showed him how to buy a bus pass and travel card.

While acknowledging that in some countries the required qualification for teaching is a teaching diploma, Dr Miller said that unless they had undertaken teacher training in the UK, or had a qualification considered to be the equivalent of a UK Bachelor's degree, recruited teachers were treated as unqualified teachers. If their qualifications were equivalent to the General Certificate of Secondary Education (GCSE) at grade C, or a higher level in Mathematics and English, they might receive a waiver, but in the case of science subjects, this would be considered only if the teacher was born after 1 September 1979 and intended to teach in a primary school. Successful completion of a training course (for example, the Overseas Trained 
Teacher Programme, the Recruited Teacher Programme or the General Teaching Programme), which led to qualified teacher status (QTS), was the sole basis on which a teacher recruited overseas could be considered to be qualified and receive the benefits of a UK trained teacher. Dr Miller's experience was that he was not given this information before he was recruited to teach in the UK.

Gaining access to QTS courses could be further complicated by the decisions of the UK National Assessment Resource Information Centre's (NARIC) comparability assessment of an individual teacher's qualifications. In Mr Miller's case, NARIC found no comparison for his Bachelor's degree, but equated his Master's degree in business administration to a UK Master's degree. There were only a limited number of places on QTS courses. In 2006, 6,800 QTS training places were available across England. Of these, 1,670 were filled by teachers trained overseas (DfES, Form 618G survey). Dr Miller also said that the preferences of the principal or head teacher could also play a major role in decisions regarding pay and admission to a QTS course. Since he had obtained qualified teacher status, he had been promoted to Head of Economics and Business Studies in his school, but other teachers had not been so fortunate.

Dr Miller then addressed the specific challenges faced by male teachers who were foreigners. They felt vulnerable and at risk of accusations of sexual or other forms of misconduct. He argued that while every teacher was at risk of being accused of misdemeanours such as assaulting a student, he felt that as a male teacher, he faced twice the risk, and as a male migrant three times the risk. This might be a consequence of racism or the personality make-up and experiences of the person responsible for the accusation. He said, for example, that in trying to break up a fight between two 8-year old pupils, he had been turned on and assaulted in his own classroom. At another school in June 2006, coincidentally on the same day that he was awarded his QTS, a female pupil whom he had asked to leave the classroom stated that he had 'touched' her in an unacceptable manner. This was still the darkest day in his teaching career. The following Monday, he was called to a meeting where written allegations and statements were put in front of him. However, after four months of investigation by the police and the child protection department, he was cleared.

In reflecting on his experience as a black male teacher, Dr Miller said that at primary level such teachers are in short supply, especially in positions of leadership. Secondly, black boys from Africa and the Caribbean were more at risk of academic failure than students from other ethnic groups. He noted that various theories, including a lack of effective role models, have been proposed to explain this. He was quite certain that his own recruitment was based on two premises: the shortage of UK teachers in the geographical area to which he moved; and the demand for teachers who could be role models and provide academic support for boys from the Caribbean and Africa.

Concluding his presentation, Dr Miller noted that during his time as a teacher in the UK he had mentored black boys and acted as an academic mentor for white female pupils. In his opinion, interaction with white pupils provided an important lense through which to understand the nuances of English culture. His interactions with black boys had provided an opportunity for them to identify with, retain and even create an 'identity of blackness' based around a 'migrant identity' and around an 'ethnic (black) identity'.

\section{Table 2: UK teacher ethnicity, 2007}

\begin{tabular}{l|c|c|}
\hline Group & 2007 & 2006 \\
\hline White & $94.6 \%$ & $94.8 \%$ \\
\hline Mixed & $0.7 \%$ & $0.7 \%$ \\
\hline Asian or Asian British & $2.4 \%$ & $2.2 \%$ \\
\hline Black or Black British & $1.7 \%$ & $1.7 \%$ \\
\hline
\end{tabular}

Source: SFR 15/2007

The increase in the percentage of teachers from minority ethnic (non-white) groups was greatest in London, 17.8 per cent in 2007 compared to 17.4 per cent in 2006. 
Table 3: Composition of the UK teaching force, 2007

\begin{tabular}{l|c|l|l|l|}
\hline $\begin{array}{l}\text { Total number of } \\
\text { teachers (2007) }\end{array}$ & 437,800 & $\begin{array}{l}600 \text { less than } \\
\text { previous year }\end{array}$ & Male (000's) & Female \\
\hline Nursery/ Primary & 196,900 & $\begin{array}{l}1200 \text { less than } \\
\text { previous year }\end{array}$ & $16 \%$ or 31,504 & $84 \%$ or $(165,396)$ \\
\hline Secondary & 216,700 & $\begin{array}{l}400 \text { more than } \\
\text { previous year }\end{array}$ & $43 \%$ or 93,181 & $57 \%$ or $(123,519)$ \\
\hline Special schools and PRUs & 21,000 & $\begin{array}{l}200 \text { more } \\
\text { previous year }\end{array}$ & N/A & N/A \\
\hline Academies & 3,200 & N/A & N/A \\
\hline
\end{tabular}

Source: DSCF, Form 618G survey, SFR 15/2007 and TDA 2007.

In conclusion, Dr Miller reflected that many migrant teachers had received support from local religious organisations and other civic groups in the UK, as well from trade unions, including the NUT. He posited a migration trajectory which presented the professional and other adjustments that the newly recruited teacher might expect to make. The first phase prepared the overseas trained teacher (OTT) for phase 2 . In phase 2 , integration was increased or restricted by the extent of prior localised knowledge (professional or otherwise) and experiences, or by the pervasive nature of experiences (often negative ones) in the previous phase. Phase 2 was the most crucial and OTTs might return to this stage several times, even after moving on to phase 3. Finally, in phase 3 (four or more years after coming to the UK), the OTT was expected to become 'properly' located within the system. This period would be facilitated if there was a successful period of induction, acquisition of localised knowledge, learning, development, integration and acculturation. At this stage, the OTT could expect to derive the best rewards (promotion, learning and other opportunities) and make their most effective professional contribution to the host system (Figure 3).

\section{Figure 3: Overseas trained teacher's identity trajectory}

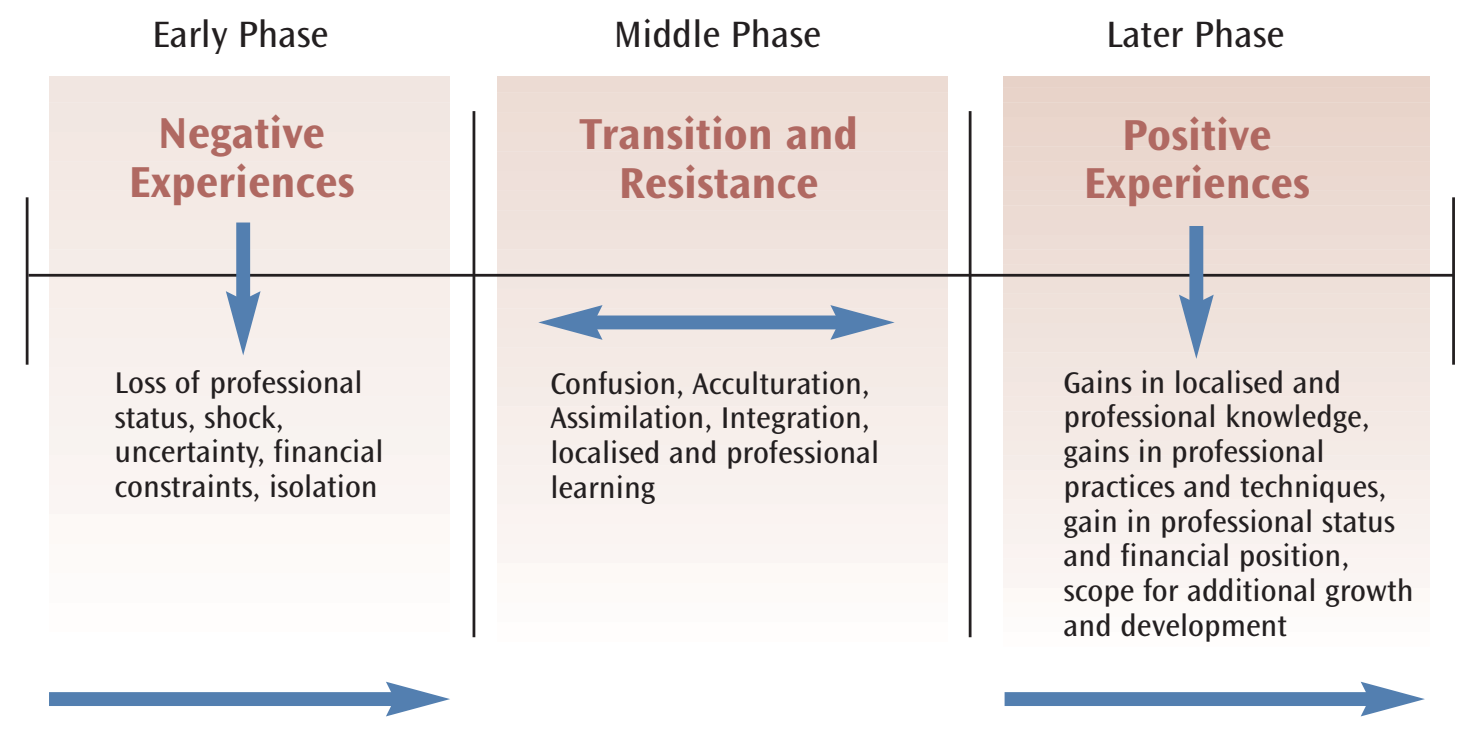

Source: Paul Miller, 2006 
In the second presentation, Dr DegazonJohnson highlighted aspects of her paper entitled 'Issues of Gender and Ethnicity in Commonwealth Teacher Recruitment and Migration - The Case of 12 Teachers'. She cited evidence that in the UK during the five-year period 1999-2003 there was targeted recruitment resulting in large scale migration of teachers from a number of Commonwealth countries in Africa, Asia and the Caribbean. These recruitment campaigns were undertaken principally to address a shortfall of teachers in the UK in general, and in England in particular. Studies by Ochs (2003) revealed that over the three-year period 2000-2002, a high volume of work permits were provided by the UK Home Office for teachers from countries such as Zimbabwe (898), Ghana (457), India (457), Canada (898), South Africa $(4,702)$ and even small Caribbean states such as Jamaica (974).
Her study of Commonwealth teacher mobility and migration specifically concerned the experiences of 12 teachers, 11 of whom were recruited to the UK during the period 2000-2004, which immediately preceded the adoption of the CTRP by ministers of education at a meeting held at Stoke Rochford, UK in 2004. The purpose of the study was to determine the kinds of experiences that Commonwealth teachers were exposed to by recruitment agencies, businesses and schools. She sought to learn from Commonwealth teachers themselves about their experiences through a combination of interviews and focus groups. The research methodology was mainly qualitative, developing case histories from the personal experiences of subjects taken from a distinct population group, teachers from Commonwealth member countries.

Table 4: Profile of qualifications and teaching experience of a sample of Commonwealth teachers recruited by UK recruitment agencies and businesses, 2001-2003 ( $=12)$

\begin{tabular}{l|l|l|l|c|l|}
\hline Case & Pseudonym & Gender & $\begin{array}{l}\text { Country } \\
\text { of origin }\end{array}$ & $\begin{array}{l}\text { Years of } \\
\text { teaching }\end{array}$ & $\begin{array}{l}\text { Academic } \\
\text { qualifications }\end{array}$ \\
\hline 1. & Alfred & Male & Zimbabwe & 14 & $\begin{array}{l}\text { Bachelor's degree and } \\
\text { post-graduate diploma }\end{array}$ \\
\hline 2. & Aurora & Female & UK & 10 & Master's degree \\
\hline 3 & David & Male & India & 17 & Master's degree \\
\hline 4. & Julius & Male & Uganda & 19 & $\begin{array}{l}\text { Bachelor's degree and } \\
\text { post-graduate diploma }\end{array}$ \\
\hline 5. & Larry & Male & Zimbabwe & 10 & Master's degree \\
\hline 6. & Mutwa & Male & Kenya & 4 & Bachelor's degree \\
\hline 7. & Ntombi & Female & South Africa & 15 & $\begin{array}{l}\text { Bachelor's degree and } \\
\text { post-graduate diploma }\end{array}$ \\
\hline 8. & Penelope & Female & Kenya & 3 & Bachelor's degree \\
\hline 9. & Sarah" & Female & Botswana & 2 & $\begin{array}{l}\text { Bachelor's degree and } \\
\text { post-graduate diploma }\end{array}$ \\
\hline 10. & Slakisha & Female & Jamaica & 10 & $\begin{array}{l}\text { Bachelor's degree and } \\
\text { post-graduate diploma }\end{array}$ \\
\hline 11. & Sonia & Female & Jamaica & 18 & $\begin{array}{l}\text { Bachelor's degree and } \\
\text { post-graduate diploma }\end{array}$ \\
\hline 12 & Sylvester & Male & Kenya & 4 & Bachelor's degree \\
\hline
\end{tabular}

Note: Names are pseudonyms used to protect teachers' anonymity. 


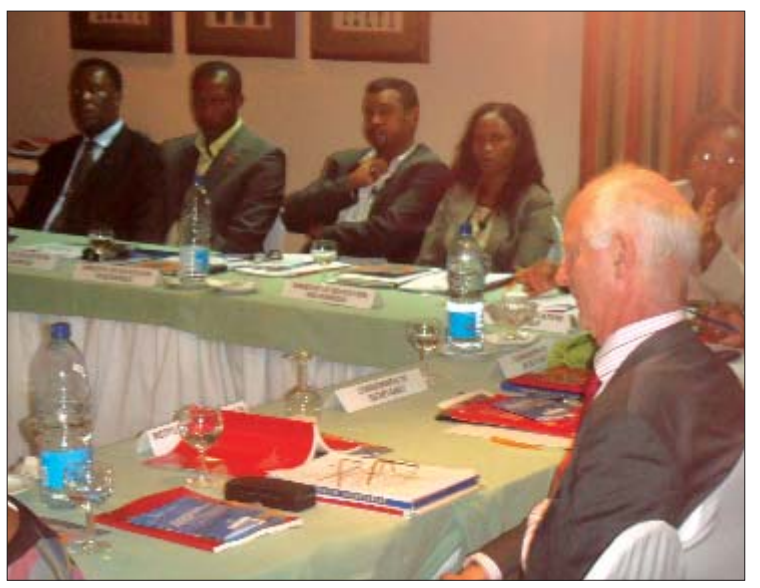

Participants and presenters at the Symposium

Of the four UK-based recruitment agencies or businesses involved, Agency ABC (a pseudonym) stood out because of the number of unethical practices to which it subjected recruited teachers. Agency ABC breached its contractual obligations by:

- Offering an annual salary and bonus to teachers to which the agency failed to adhere;

- Unilaterally coercing recruits into changing their contract mid-year without their prior knowledge or agreement, and rescinding one-year contractual agreements;

- Changing the emoluments by at first agreeing to pay a fixed salary, whether or not teachers were working, thereby treating them as employees of the agency, only to change this after a matter of months to payment only for days worked;
- Using the threat of withdrawal of UK Home Office work permits to coerce teachers into accepting new terms;

- Apparently misleading recruits by giving the impression that supply teaching was a temporary arrangement which would lead to a permanent jobs, when there is some evidence that the agency sought to prevent some teachers from obtaining a permanent appointment, as this would have led to loss of revenue;

- Charging a fee for finding accommodation and then providing accommodation that was grossly sub-standard.

Dr Degazon-Johnson concluded her presentation by acknowledging the tremendous contribution to the welfare of teachers recruited from overseas made by the NUT, which was also the convener of the Commonwealth Teachers Group. She expressed her pleasure at the outstanding initiative of Commonwealth ministers of education, who developed and created the CTRP for the protection of teachers, a critical human resource.

(For the full text of the presentation see Appendix 3.)

The first day of the symposium concluded with the launch of Teacher Supply, Recruitment and Retention in Six Sub-Saharan African Countries by Dennis Sinyolo, published by Education International. 
